\title{
ANALISIS PENYELESAIAN SENGKETA KONSUMEN MELALUI BADAN PENYELESAIAN SENGKETA KONSUMEN ( BPSK )
}

\author{
Yustiana Dwirainaningsih \\ Politeknik Pusmanu Pekalongan \\ Korespondensi: dwirainaningsih@gmail.com
}

\begin{abstract}
Factually, consumer disputes will always exist in everyday life, in the process of consumer dispute resolution can be done in two ways, namely settlement using litigation lines (through court) and non litigation where the settlement is carried out by the Consumer Dispute Settlement Agency (BPSK) by mediation, consolidation and abritase. This research was conducted at the Consumer Dispute Settlement Agency based in Pekalongan City by using a type and normative juridical approach. The author reviews the legal literature about consumer protection and consumer dispute resolution on consumer protection laws which are then collected and classified with notes in detailed, systematic and directed documents/literature. Next, the writer analyzes the data descriptively, so that a comprehensive picture of the problems surrounding consumer dispute resolution in BPSK in Pekalongan City is obtained. The results of the research that the authors did revealed the role of Pekalongan City BPSK in efforts to resolve consumer disputes based on Law Number 8 of 1999 concerning Consumer Protection which can be reached by 3 (three) methods / methods, namely conciliation, mediation and arbitration on the basis of choice and approval the parties to the dispute. The form of the decision with the method of conciliation and mediation is final and binding, without having to request fiat execution to the local District Court, while the form of decision taken by the arbitration method must be requested for fiat to the local District Court so that the arbitral award has executorial power.
\end{abstract}

Keywords: Consumer Dispute Settlement Agency, Consumer Dispute, Consumer Dispute Resolution

\begin{abstract}
ABSTRAK
Secara faktual bahwa sengketa konsumen akan selalu ada dalam kehidupan sehari-hari, dalam proses penyelesaian sengketa konsumen dapat dilakukan dengan dua jalur yaitu penyelesaian menggunakan jalur litigasi (melalui pengadilan) dan non litigasi di mana penyelesaiannya dilakukan oleh Badan Penyelesaian Sengketa Konsumen (BPSK) dengan cara mediasi, konsolidasi dan abritase. Penelitian ini dilakukan pada Badan Penyelesaian Sengketa Konsumen yang berkedudukan di Kota Pekalongan dengan menggunakan jenis dan pendekatan yuridis normatif. Penulis melakukan penelaahan literatur hukum seputar perlindungan konsumen serta penyelesaian sengketa konsumen terhadap undangundang perlindungan konsumen yang kemudian dikumpulkan dan diklasifikasikan dengan catatan secara rinci, sistematis dan terarah mengenai dokumen/kepustakaan. Selanjutnya penulis menganalisa data secara deskriptif, sehingga diperoleh gambaran yang menyeluruh tentang permasalahanpermasalahan seputar penyelesaian sengketa konsumen di BPSK Kota Pekalongan. Hasil dari penelitian yang penulis lakukan ini mengemukakan peran BPSK Kota Pekalongan dalam upaya penyelesaian sengketa konsumen ditinjau berdasarkan Undang-undang Nomor 8 Tahun 1999 tentang Perlindungan Konsumen dapat ditempuh dengan 3 (tiga) metode/cara yaitu konsiliasi, mediasi dan arbitrase atas dasar pilihan dan persetujuan para pihak yang bersengketa. Bentuk putusan dengan metode konsiliasi dan mediasi bersifat final dan mengikat, tanpa harus dimintakan fiat eksekusi ke Pengadilan Negeri setempat, sedangkan bentuk putusan yang ditempuh dengan metode arbitrase harus dimintakan fiat eksekusi ke Pengadilan Negeri setempat agar putusan arbitrase tersebut mempunyai kekuatan eksekutorial.
\end{abstract}

Kata Kunci: Badan Penyelesaian Sengketa Konsumen, Sengketa Konsumen, Penyelesaian Sengketa Konsumen

\section{PENDAHULUAN}

Pesatnya perkembangan ekonomi nasional telah menghasilkan diversifikasi produk barang dan/atau jasa yang dapat dikonsumsi oleh masyarakat. Kemajuan ilmu 
pengetahuan, teknologi komunikasi dan informatika juga turut mendukung perluasan ruang gerak transaksi barang dan/jasa hingga melintasi batas-batas wilayah suatu negara. Kondisi yang demikian pada satu pihak sangat bermanfaat bagi kepentingan konsumen karena kebutuhan akan barang dan/ atau jasa yang diinginkan dapat terpenuhi serta semakin terbuka lebar kebebasan untuk memilih aneka jenis kualitas barang dan/atau jasa sesuai dengan kemampuannya. ${ }^{1}$ Di sisi lain, kondisi dan fenomena tersebut dapat mengakibatkan kedudukan pelaku usaha dan konsumen menjadi tidak seimbang, dimana konsumen cenderung dijadikan obyek aktivitas bisnis dari pelaku usaha untuk meraup keuntungan sebesar-besarnya melalui kiat iklan, promosi, cara penjualan, serta penerapan perjanjian standar yang merugikan konsumen. ${ }^{2}$

Masyarakat luas sebagai konsumen sudah seharusnya diberikan perlindungan karena seringkali tidak berdaya dalam menghadapi kegiatan perdagangan sehari-hari. Permasalahan yang dihadapi konsumen Indonesia, seperti juga yang dialami di negaranegara berkembang lainnya, tidak hanya sekedar memilih barang, tetapi jauh lebih kompleks dari itu menyangkut pada penyadaran semua pihak, baik itu pengusaha, pemerintah maupun konsumen sendiri tentang pentingnya perlindungan konsumen ${ }^{3}$

Faktor utama yang menjadi kelemahan konsumen adalah tingkat kesadaran konsumen akan hak-haknya yang masih rendah. Hal ini disebabkan oleh rendahnya pendidikan konsumen. Oleh karena itu kehadiran Undang-Undang Perlindungan Konsumen dimaksudkan menjadi landasan hukum kuat bagi pemerintahan dan lembaga perlindungan konsumen swadaya masyarakat untuk melakukan upaya pemberdayaan konsumen melalui pembinaan dan pendidikan konsumen

Undang-undang tentang Perlindungan Konsumen Nomor 8 Tahun 1999 (UUPK) adalah ketentuan mengenai penyelesaian sengketa konsumen, menjadi salah satu permasalahn dalam menyelesaikan kasus yang terkait dengan konsumen. Dalam menyelesaikan sengketa konsumen, Pasal 45 Ayat (1) UUPK memang menyebutkan bahwa penyelesaian sengketa konsumen dapat ditempuh melalui pengadilan atau di luar pengadilan berdasarkan pilihan sukarela para pihak yang bersengketa. Namun, ini tidak berarti dalam mengajukan gugatan harus telah disetujui dahulu oleh para pihak. Menurut penjelasan pasal 45, ini artinya dalam penyelesaian sengketa konsumen tidak menutup kemungkinan penyelesaian damai oleh para pihak yang bersengketa. Pada setiap tahap diusahakan untuk menggunakan penyelesaian damai oleh kedua belah pihak yang bersengketa. Jadi, pengajuan gugatannya tidak harus atas persetujuan para pihak, tetapi para pihak dapat bersepakat untuk memilih perdamaian untuk penyelesaian sengketanya. konsumen dapat menggugat pelaku usaha ke BPSK atau ke badan peradilan. Namun, dalam hal sengketa itu bukan kewenangan BPSK, Ketua BPSK dapat menolak permohonan penyelesaian sengketa konsumen (lihat pasal 17 Kepmenperindag 350/2001).

Sengketa dalam pengertian sehari-hari dimaksudkan sebagai suatu keadaan di mana pihak-pihak yang melakukan upaya-upaya perniagaan mempunyai masalah yaitu menghendaki pihak lain untuk berbuat atau tidak berbuat sesuatu tetapi pihak lainnya menolak atau tidak berlaku demikian. Sengketa juga dapat dimaksudkan sebagai adanya

\footnotetext{
${ }^{1}$ Penjelasan umum atas Undang-Undang Republik Indo- nesia No. 8 Tahun 1999 tentang Perlindungan Konsumen (Lembagan Negara RI Tahun 1999 Nomor 42)

${ }^{2}$ Kurniawan "permasalahan dan kendala penyelesaian sengketa konsumen melalui BPSK" Jurnal Dinamika Hukum, Volume 12 No. 1 tahun 2012

${ }^{3}$ AZ. Nasution, Hukum Perlindungan Konsumen: Suatu Pengantar, Cetakan Keempat, (Jakarta: Diadit Medika, 2011), hal 8
} 
ketidakserasian antara pribadi-pribadi atau kelompok-kelompok yang mengadakan hubungan karena hak salah satu pihak terganggu atau dilanggar ${ }^{4}$

Adapun mengenai pengertian dari sengketa konsumen itu sendiri menurut menteri perdagangan dalam surat keputusannya adalah:

"Yang dimaksud dengan sengketa konsumen adalah sengketa antara pelaku usaha dengan konsumen yang menuntut ganti rugi atau kerusakan, pencemaran dan/atau yang menderita kerugian akibat mengkonsumsi barang atau memanfaatkan jasa. "5

Sengketa konsumen adalah sengketa yang terjadi antara konsumen di satu pihak dan pelaku usaha atau produsen di pihak lain. Konsumen sebagai pengguna/pemakai barang dan/atau jasa dan pelaku usaha atau produsen sebagai penyedia barang atau jasa. barang atau jasa yang dapat menjadi objek sengketa adalah produk konsumen. barang atau jasa yang dapat menjadi objek sengketa adalah produk konsumen, yaitu barang atau jasa yang umumnya digunakan konsumen untuk memenuhi kebutuhan hidupnya, keluarga, rumah tangga dan tidak untuk diperdagangkan.

Apabila penyelesaian sengketa konsumen dilakukan di luar peradilan menurut Pasal 52 UUPK adalah melalui Badan Penyelesaian Sengketa Konsumen (BPSK), dengan cara melalui mediasi, arbitrase,dan konsiliasi.Gugatan yang sudah diajukan ke BPSK harus ditindaklanjuti oleh BPSK, dan BPSK wajib memberikan putusan. Putusan tersebut berdasarkan Pasal 56 Ayat (2) UUPK bersifat final dan mengikat, dengan kata lain tidak dapat dilakukan banding dan kasasi. Akan tetapi berdasarkan Pasal 54 Ayat (3) UUPK terhadap putusan tersebut dapat dimintakan upaya hukum (keberatan) ke pengadilan Negeri. Peluang mengajukan keberatan atas putusan BPSK kepada Pengadilan Negeri adalah bentuk campur tangan demikian besar dari lembaga peradilan umum terhadap penyelesaian sengketa melalui BPSK. Artinya kekuatan putusan dari BPSK secara yuridis masih digantungkan pada supremasi pengadilan sehingga tidak benar-benar final. Sementara dalam praktek pengajuan keberatan atas putusan BPSK di pengadilan Negeri berlaku hukum secara perdata umum, sehingga menambah panjang proses penyelesaian sengketa konsumen. Persoalan lainnya adalah dalam eksekusi terhadap putusan BPSK, agar mempunyai kekuatan eksekusi, putusan BPSK harus dimintakan penetapan eksekusi ke pengadilan, tetapi aturan mengenai tatacara permohonan eksekusi terhadap putusan BPSK tersebut belum ada. ${ }^{6}$

Maka atas dasar latar belakang masalah yang diuraikan di atas, penulis bertujuan melakukan penelitian dengan judul "Analisis penyelesaian Sengketa konsumen melalui badan penyelesaian sengketa konsumen (BPSK)".

\section{LANDASAN TEORI}

\subsection{Dasar Hukum Perlindungan Konsumen}

Hukum perlindungan konsumen selalu berhubungan dengan berbagai bidang dan cabang hukum lain, karena pada tiap bidang dan cabang hukum itu senantiasa terdapat pihak yang berpredikat sebagai "konsumen". Oleh karena itu, ruang lingkup hukum perlindungan konsumen sulit dibatasi hanya dengan menampungnya dalam satu jenis undang-undang yaitu Undang-Undang

\footnotetext{
${ }^{4}$ Soerjono Soekanto, Mengenai Antropologi hukum, (Bandung: Alumni, 1979), hal. 29 dalam Halim Barkatullah

${ }_{5}^{5}$ Pemerintah Republik Indonesia, Surat Keputusan Menteri Perindustrian dan Perdagangan Nomor: 350/MPP/Kep/12/2001 tanggal: 10 Desember 2001.

${ }^{6}$ Muskibah "Analisis mengenai cara penyelesaian sengketa konsumen ” Fakultas Hukum Universitas Jambi
} 
Perlindungan Konsumen (UUPK). Memahami antara hukum konsumen dan hukum perlindungan konsumen dan keterkaitan antara hak-hak pokok dari konsumen dan keterkaitan antara hukum perlindungan konsumen dengan bidang-bidang hukum yang lain dapat memberikan gambaran menyeluruh tentang hukum perlindungan konsumen $^{7}$

Pada hakekatnya, terdapat dua instrumen hukum penting yang menjadi landasan kebijakan perlindungan konsumen di Indonesia, yakni:

Pertama, Undang-Undang Dasar 1945, sebagai sumber dari segala sumber hukum di Indonesia, mengamanatkan bahwa pembangunan nasional bertujuan untuk mewujudkan masyarakat adil dan makmur. Tujuan pembangunan nasional diwujudkan melalui sistem pembangunan ekonomi yang demokratis sehingga mampu menumbuhkan dan mengembangkan dunia yang memproduksi barang dan jasa yang layak dikonsumsi oleh masyarakat.

Kedua, Undang-Undang No. 8 Tahun 1999 tentang Perlindungan Konsumen (UUPK). Lahirnya Undang-undang ini memberikan harapan bagi masyarakat Indonesia, untuk memperoleh perlindungan atas kerugian yang diderita atas transaksi suatu barang dan jasa. UUPK menjamin adanya kepastian hukum bagi konsumen.

Undang-Undang No. 8 Tahun 1999 tentang Perlindungan Konsumen tidak memuat definisi mengenai hukum perlindungan konsumen tetapi memuat perumusan mengenai perlindungan konsumen yaitu sebagai "segala upaya yang menjamin adanya kepastian hukum untuk memberikan perlindungan kepada konsumen." Apabila Konsumen benar-benar akan dilindungi, maka hak-hak konsumen harus dipenuhi, baik oleh negara maupun oleh pelaku usaha, karena pemenuhan hak-hak konsumen tersebut akan melindungi kerugian konsumen dari berbagai aspek.

Dalam pasal 2 UUPK, dinyatakan bahwa perlindungan hukum bagi konsumen diselenggarakan sebagai usaha bersama berdasarkan 5 (lima) prinsip dalam pembangunan nasional, yaitu:

1) Prinsip manfaat. Dimaksudkan untuk mengamanatkan bahwa segala upaya dalam penyelenggaraan perlindungan konsumen harus memberi manfaat sebesar-besarnya bagi kepentingan konsumen dan pelaku usaha secara keseluruhan;

2) Prinsip keadilan, dimaksudkan agar partisipasi seluruh rakyat dapat diwujudkan secara maksimal dan memberikan kesempatan kepada konsumen dan pelaku usaha untuk memperoleh haknya dan melaksanakan kewajibannya secara adil;

3) Prinsip keseimbangan, dimaksudkan untuk memberikan keseimbangan antara kepentingan konsumen, pelaku usaha dan pemerintah;

4) Prinsip keamanan dan keselamatan konsumen, dimaksudkan untuk memberi jaminan atas keamanan dan keselamatan kepada konsumen dalam penggunaan, pemakaian dan pemanfaatan barang dan/atau jasa yang digunakan;

${ }^{7}$ Penyelesaian Sengketa Konsumen Melalui Badan Penyelesaian Sengketa Konsumen (BPSK) Kota Serang dalam AJUDIKASI : Jurnal Ilmu Hukum, Vol. 2 No. 1, Juni 2018 
5) Prinsip kepastian hukum, dimaksudkan agar baik pelaku usaha maupun konsumen menaati hukum dan memperoleh keadilan dalam penyelenggaraan perlindungan hukum bagi konsumen, di mana negara dalam hal ini turut menjamin adanya kepastian hukum tersebut

\section{METODE PENELITIAN}

Jenis dan pendekatan penelitian yang digunakan adalah penelitian yuridis normatif, yaitu hukum dikonsepsi sebagai norma, kaidah, asas atau dogma-dogma dengan pendekatan penelitian melalui studi kepustakaan yaitu dengan melakukan penelahaan terhadap bahan pustaka/literatur yang berkaitan seputar perlindungan konsumen serta penyelesaian sengketa konsumen yang ditempuh di luar pengadilan khususnya penyelesaian sengketa melalui Badan Penyelesaian Sengketa (BPSK). Dalam penelitian ini analisa data dilakukan secara kualitatif normatif yakni analisa yang dipakai tanpa menggunakan angka maupun rumusan statistika dan matematika artinya disajikan dalam bentuk uraian. Dimana hasil analisis akan dipaparkan secara deskriptif, dengan harapan dapat menggambarkan secara jelas mengenai proses hukum penyelesaian sengketa konsumen melalui Badan Penyelesaian Sengketa Konsumen, sehingga diperoleh gambaran yang menyeluruh tentang permasalahan-permasalahan yang diteliti

\section{PEMBAHASAN}

\subsection{Proses penyelesaian sengketa}

Secara harafiah arti consumer itu adalah (lawan dari produsen) setiap orang yang menggunakan barang. Tujuan penggunaan barang atau jasa itu nanti menentukan termasuk konsumen kelompok mana pengguna tersebut. Begitu pula Kamus Bahasa Inggris-Indonesia memberi arti kata consumer sebagai "pemakai atau konsumen". Dalam peraturan perundangan di Indonesia, istilah "konsumen" sebagai definisi yuridis formal ditemukan pada UUPK. Konsumen adalah setiap orang pemakai barang dan atau jasa yang tersedia dalam masyarakat, baik bagi kepentingan sendiri, keluarga, orang lain maupun makhluk hidup lain dan tidak untuk diperdagangkan

Pelaku usaha, masyarakat umum biasanya menyebutnya dengan sebutan produsen. Terkadang masyarakat mengartikan produsen sebagai pengusaha, namun ada pula pendapat yang mengatakan bahwa produsen hanya penghasil barang saja dan merupakan salah satu unsur dari pengusaha. UUPK menggunakan istilah Pelaku Usaha. Menurut Pasal 1 Angka 3, pengertian Pelaku Usaha adalah Setiap orang perorangan atau badan usaha, baik yang berbentuk badan hukum maupun bukan badan hukum yang didirikan dan berkedudukan di wilayah hukum negara Republik Indonesia, baik sendiri mapun bersama-sama melalui perjanjian penyelenggaraan kegiatan usaha dalam berbagai bidang ekonomi.

Undang-Undang Nomor 8 Tahun 1999 Tentang Perlindungan Konsumen (UUPK), yang mengatur tentang perlindungan terhadap konsumen menegaskan dalam Pasal 1 ayat (1) bahwa perlindungan konsumen adalah segala upaya yang menjamin adanya kepastian hukum untuk memberikan perlindungan kepada konsumen. Dengan kata lain UUPK secara tegas telah memberikan jaminan perlindungan terhadap konsumen, jika konsumen dirugikan oleh pelaku usaha.

Penyelesaian sengketa yang terjadi antara konsumen dan pelaku usaha,dapat diselesaikan melalui jalur litigasi (melalui pengadilan) dan jalur nonlitigasi (tidak 
melalui pengadilan).Penyelesaian, melalui lembaga litigasi dianggap kurang efisien baik waktu, biaya, maupun tenaga,sehingga penyelesaian melalui lembaga non litigasi banyak dipilih oleh masyarakat dalam menyelesaikan sengketa dimaksud. Meskipun demikian pengadilan juga tetap akan menjadi muara terakhir bila di tingkat non litigasi tidak menemui kesepakatan. ${ }^{8}$

Sebagai lembaga yang berwenang menangani dan menyelesaikan sengketa antara pelaku usaha dengan konsumen, BPSK dalam kewenangannya dapat menempuhnya dengan cara mediasi, konsiliasi atau arbitrase. UU perlindungan konsumen tidak mendefinisikan apa itu mediasi, konsiliasi atau arbitrase di bidang perlindungan konsumen. Hal ini kemudian dijelaskan lebih jauh dalam Keputusan Menperindag No. 350 Tahun 2001 tentang Tugas dan Wewenang BPSK.

Dalam Kepmen tersebut, mediasi diartikan sebagai proses penyelesaian sengketa konsumen di luar pengadilan dengan BPSK sebagai penasehat dan penyelesaiannya diserahkan kepada para pihak. Proses konsiliasi mirip dengan mediasi. Bedanya, dalam proses konsiliasi, BPSK hanya mempertemukan para pihak yang bersengketa. Sementara arbitrase adalah proses penyelesaian sengketa konsumen di luar pengadilan yang dalam hal ini para pihak yang bersengketa menyerahkan sepenuhnya penyelesaian sengketa kepada BPSK. ${ }^{9}$

Ada beberapa kendala utama yang dihadapi BPSK dalam mengimplementasikan UU perlindungan konsumen.

1. Kendala Kelembagaan.

2. Kendala Pendanaan.

3. Kendala Sumber Daya Manusia BPSK.

4. Kendala Peraturan.

5. Kendala Pembinaan dan Pengawasan, dan Rendahnya Koordinasi antara Aparat Penanggung Jawab.

6. Kendala Kurangnya Sosialisai terhadap Kebijakan Perlindungan Konsumen.

7. Kendala Kurangnya Respon Masyarakat Terhadap UU Perlindungan Konsumen dan lembaga BPSK.

Dalam putusan BPSK mestinya harus dipandang sebagai putusan yang mempunyai kekuatan hukum yang tetap (inkracht van gewijsde), sesuai dengan Pasal 54 Ayat (3) UU Perlindungan Konsumen, putusan BPSK dari hasil konsilitasi, arbitrase,dan mediasi bersifat final dan mengikat.Final berarti dan sebagai sesuatu yang harus dijalankan para pihak. Prinsip res judicata pro vitatate habetur-suatu putusan yang tidak mungkin lagi untuk dilakukan upaya hukumdinyatakan sebagai putusan yang mempunyai kekuatan hukum pasti. ${ }^{10}$

Tetapi dalam Pasal 56 Ayat (2) UU Perlindungan Konsumen.Para pihak ternyata masih bias mengajukan ' keberatan' ke Pengadilan Negeri paling lambat 14 hari setelah pemberitahuan BPSK. Hal ini bertentangan dengan sifat putusan BPSK yang bersifat final dan mengikat.

Masalah juga timbul pada saat eksekusi. Agar mempunyai kekuatan eksekusi, putusan BPSK harus dimintakan penetapan (fiat eksekusi) ke pengadilan.

\footnotetext{
${ }^{8}$ Aries Kurniawan, Peranan Badan Penyelesaian Sengketa Konsumen Dalam Penyelesaian Sengketa Konsumen, Kompas 6 Agustus 2008, hlm.3

9 Muskibah, Op.cit "Analisis mengenai cara penyelesaian sengketa konsumen"

${ }^{10}$ Susanti Adi Nugroho, Mencari Ujung Tombak Penyelesaian Sengketa Konsumen, Hukum Online, 9 Mei 2009
} 
Dalam praktek, tidak mungkin memintakan penetapan eksekusi karena belum ada peraturan atau petunjuk tentang tata cara pengajuan keberatan terhadap putusan BPSK. Perma No. I Tahun 2006 tentang cara pengajuan keberatan terhadap putusan BPSK pada hakikatnya hanya mengatur mengenai pengajuan keberatan terhadap putusan BPSK. Pasal 2 Perma ini menegaskan bahwa yang bias diajukan keberatan adalah terhadap putusan arbitrase BPSK. Sedangkan keberatan mengenai putusan konsiliasi atau mediasi, serta penetapan eksekusi sama sekali tidak diatur. ${ }^{11}$

Permohonan eksekusi dapat dilakukan baik terhadap putusan BPSK maupun putusan keberatan, namun UUPK tidak menyediakan peraturan yang lebih rinci berkaitan dengan hal tersebut. Pelaksanaan putusan arbitrase diserahkan dan menjadi wewenang penuh dari Pengadilan Negeri yang menjalankan fungsi kekuasaan kehakiman, dan mempunyai legitimasi sebagai lembaga pemaksa. Adapun tata cara melaksanakan putusan Hakim diatur dalam Pasal 195 sampai dengan Pasal 208 HIR. Ketentuan mengenai prosedur permohonan eksekusi tidak diatur secara rinci dan jelas dalam UUPK. Pasal 57 UUPK menjelaskan bahwa putusan majelis dimintakan penetapan eksekusinya kepada Pengadilan Negeri di tempat konsumen dirugikan.

Kehadiran BPSK yang dibentuk pemerintah, semestinya bisa menjadi bagian dari upaya perlindungan konsumen ketika sengketa dengan pelaku usaha. Pemerintah sebagai institusi pembentuk BPSK rasanya kurang serius dalam pengembangan BPSK sehingga benar-benar bisa menjadi optimal.Kesan umum yang nampak baik pemerintah pusat maupun daerah lebih sibuk mengejar dan melayani investor dari pada memikirkan kepentingan publik termasuk hak-hak konsumen.

Di antara kendala-kendala yang bersifat multidimensi dalam pengelolaan BPSK, terdapat dua hal yang menjadi sumber persoalan yakni keberadaan peraturan perundang-undangan dan sumber daya manusia. Kedua persoalan tersebut saling terkait dan menyebabkan munculnya persoalan-persoalan lain yang mengakibatkan kurang berperannya BPSK selama ini.

Selain hal tersebut diatas persyaratan bagi anggota BPSK yang diatur dalam Kepmenperindag RI No. 301/MPP/Kep/10/2001 tentang Pengangkatan, Pemberhentian, Anggota dan Sekretariat BPSK Nampak lebih mengedepankan aspek formal dari pada kapasitas maupun kompetensinya. Misalnya saja persyaratan pangkal/ golongan tertentu, bagi anggota BPSK dari unsur pemerintah seringkali mempersulit dalam pencarian dan perekrutan orang yang tepat. Pada umumnya pegawai pemerintah di daerah dengan golongan pangkat tersebut telah menduduki jabatan yang penting. Establish dan tentunya' amat sibuk' dengan tugas dinasnya sehingga sulit terlibat aktif dan progresif di BPSK. Padahal SDM sangat penting dalam menunjang operasional dan pengembangan BPSK.

\subsection{Peran Badan Penyelesaian Sengketa Konsumen}

Badan Penyelesaian Sengketa Konsumen Kota Serang terbentuk pada tahun 2011 berdasarkan Keputusan Menteri Perdagangan, No. 305/MDAG/KEP/5/2011 sesuai dengan amanat Undang-Undang No. 8 Tahun 1999 Terbentuknya Badan Penyelesaian Sengketa Konsumen Kota pekalongan dengan mewujudkan upaya

11 Ibid, Muskibah 
penyelesaian sengketa konsumen dalam rangka pemberdayaan dan perlindungan masyarakat sehinggatercapainya peningkatan kualitas barang dan pelayanan jasa di Kota Pekalongan dan sekitarnya.

Badan Penyelesaian Sengketa Konsumen disingkat sebagai BPSK adalah salah satu lembaga peradilan konsumen berkedudukan pada tiap Daerah Tingkat II kabupaten dan kota di seluruh Indonesia sebagaimana diatur menurut Undangundang No.8 tahun 1999 tentang Perlindungan Konsumen bertugas utama menyelesaikan persengketaan konsumen di luar lembaga pengadilan umum, BPSK beranggotakan unsur perwakilan aparatur pemerintah, konsumen dan pelaku usaha atau produsen yang diangkat atau diberhentikan oleh Menteri, dalam menangani dan mengatur permasalahan konsumen,

Badan Penyelesaian Sengketa Konsumen (BPSK) merupakan suatu lembaga khusus yang dibentuk dan diatur dalam Undang-Undang Perlindungan Konsumen, yang tugas utamanya adalah menyelesaikan sengketa atau perselisihan antara konsumen dan pelaku usaha.

BPSK memiliki kewenangan untuk melakukan pemeriksaan atas kebenaran laporan dan keterangan dari para pihak yang bersengketa, melihat atau meminta tanda bayar, tagihan atau kuitansi, hasil test lab atau bukti-bukti lain, keputusan Badan Penyelesaian Sengketa Konsumen (BPSK) bersifat mengikat dan penyelesaian akhir bagi para pihak.

Menurut Erman Rajagukguk, budaya hukum masyarakat termasuk faktor yang mempengaruhi arti penting penyelesaian sengketa bisnis di luar pengadilan. Budaya tradisional yang menekankan kepada komunitas, kekerabatan, harmoni, primus inter pares telah mendorong penyelesaian sengketa di luar pengadilan yang formal. Demikian budaya yang menekankan kepada efisiensi dan efektifitas sama kuatnya mendorong penyelesaian sengketa bisnis tanpa melalui pengadilan. ${ }^{12}$

Keberadaan BPSK diharapkan menjadi alternatif bagi kejenuhan dan keperihatinan masyarakat terhadap sistem peradilan di Indonesia. Namun, ternyata UUPK tidak secara tuntas memberikan peran kepada BPSK sebagai suatu lembaga alternatif penyelesaian sengketa konsumen. Ada beberapa persoalan yang dihadapi dalam praktik, yaitu menyangkut eksistensi dari lembaga BPSK. Persoalan lainnya yang krusial adalah menyangkut tugas dan kewenangan BPSK. Ketentuan Pasal 54 ayat (3) UUPK bahwa putusan BPSK bersifat "final dan mengikat" kehilangan makna dan menjadi tidak berarti bagi konsumen yang mencari keadilan melalui BPSK, ketika dihadapkan dengan ketentuan Pasal 56 ayat (2) dimana terbukanya peluang mengajukan keberatan ke Pengadilan Negeri.

Perlindungan konsumen menurut Pasal 1 angka 1 UUPK adalah segala upaya yang memberikan kepastian untuk memberikan perlindungan kepada konsumen. Kepastian hukum yang dimaksud dalam pengertian ini meliputi segala upaya untuk memberdayakan konsumen memperoleh atau menentukan pilihannya atas barang/atau jasa kebutuhannya serta mempertahankan atau membela hakhaknya apabila di rugikan oleh perilaku pelaku usaha penyedia kebutuhan

\footnotetext{
${ }^{12}$ Erman Rajagukguk, "Budaya Hukum dan Penyelesaian Sengketa Perdata di Luar Pengadilan”, Jurnal Magister Hukum,
} PPs-UII, Yogyakarya, Volume. 2 No. 4, Oktober 2000. hlm. 7 
konsumen tersebut. ${ }^{13}$

BPSK diadopsi dari model Small Claim Tribunal (SCT) yang telah berjalan efektif di negara-negara maju, namun BPSK ternyata tidak serupa dengan SCT. Sebagaimana diketahui $S C T$ berasal dari negara-negara yang bertradisi atau menganut sistem hukum Common Law atau Anglo Saxon memiliki cara berhukum yang sangat dinamis dimana yurisprudensi menjadi hal utama dalam penegakan hukum. Sedangkan Indonesia sistem hukumnya adalah Civil Law atau Eropa Kontinental yang cara berhukumnya bersumber dari hukum tertulis (peraturan perundang-undangan). ${ }^{14}$

BPSK adalah badan yang bertugas menangani dan menyelesaikan sengketa antara pelaku usaha dan konsumen. BPSK sebenarnya dibentuk untuk menyelesaikan kasus-kasus sengketa konsumen yang berskala kecil dan bersifat sederhana (Pasal 1 butir 11 UUPK). Dasar hukum pembentukan BPSK adalah Pasal 49 Ayat 1 UUPK dan Kepmenperindag Nomor 350/MPP/ Kep/12/2001 yang mengatur bahwa di setiap kota atau kabupaten harus dibentuk BPSK.

Tugas BPSK melaksanakan penanganan dan penyelesaian sengketa konsumen, dengan cara melalui mediasi atau arbitrase atau konsiliasi; memberikan konsultasi perlindungan konsumen; melakukan pengawasan terhadap pencantuman klausula baku; melaporkan kepada penyidik umum apabila terjadi pelanggaran ketentuan dalam Undang-undang No.8 tahun 1999 tentang Perlindungan Konsumen; menerima pengaduan baik tertulis maupun tidak tertulis, dari konsumen tentang terjadinya pelanggaran terhadap perlindungan konsumen; melakukan penelitian dan pemeriksaan sengketa perlindungan konsumen; memanggil pelaku usaha yang diduga telah melakukan pelanggaran terhadap perlindungan konsumen; memanggil dan menghadirkan saksi, saksi ahli dan/atau setiap orang yang dianggap mengetahui pelanggaran terhadap Undang-undang No.8 tahun 1999 tentang Perlindungan Konsumen; meminta bantuan penyidik untuk menghadirkan pelaku usaha, saksi, saksi ahli, atau setiap orang atau pihak yang tidak bersedia memenuhi panggilan badan penyelesaian sengketa konsumen; mendapatkan, meneliti dan/atau menilai surat, dokumen, atau alat bukti lain guna penyelidikan dan/atau pemeriksaan; memutuskan dan menetapkan ada atau tidak adanya kerugian di pihak konsumen; memberitahukan putusan kepada pelaku usaha yang melakukan pelanggaran terhadap perlindungan konsumen; menjatuhkan sanksi administratif kepada pelaku usaha yang melanggar ketentuan Undang-undang.

Kewenangan untuk menangani dan menyelesaikan sengketa konsumen, Badan Penyelesaian Sengketa Konsumen membentuk majelis harus ganjil dan sedikit-dikitnya berjumlah anggota majelis tiga orang terdiri dari seorang ketua merangkap anggota, seorang wakil ketua merangkap anggota, dan seorang anggota, majelis ini terdiri mewakili semua unsur yaitu unsur pemerintah, unsur konsumen, dan unsur pelaku usaha serta dibantu oleh seorang panitera dan putusan majelis bersifat final dan mengikat.

\footnotetext{
${ }^{13}$ Az. Nasution, “Aspek Hukum Perlindungan Konsumen”, Jurnal Teropong, Edisi Mei 2003, Masyarakat Pemantau Peradilan Indonesia, hlm. 6-7.

${ }^{14}$ Di Indonesia dikenal Asas Nullun Delictum Nulla Poena Sine Praevia Lege Poenali atau asas Legalitas dimana asas ini mengandung arti tidak ada suatu perbuatan yang dapat dijatuhi pidana kecuali atas kekuatan peraturan pidana dalam Perundang-undangan yang telah ada sebelum perbuatan tersebut dilakukan.
} 
Prosedurnya cukup sederhana, konsumen yang bersengketa dengan pelaku usaha bisa langsung datang ke BPSK Provinsi dimana mereka berada dengan membawa permohonan penyelesaian sengketa, mengisi form pengaduan dan juga berkas-berkas/dokumen yang mendukung pengaduannya. Pihak-pihak yang berpekara di BPSK tidak dikenai biaya perkara alias gratis. Sementara biaya operasional BPSK ditanggung APBD. Selain bebas biaya, prosedur pengaduan konsumen. pun cukup mudah, yaitu hanya membawa barang bukti atau bukti pembelian/pembayaran, dan kartu identitas (KTP). Formulir pengaduan disediakan di sekretariat BPSK. Pihak BPSK lalu akan melakukan pemanggilan pada pihakpihak yang bersengketa guna dipertemukan dalam prasidang.

Dari prasidang itu bisa ditentukan langkah selanjutnya apakah konsumen dan pelaku usaha masih bisa didamaikan atau harus menempuh langkah-langkah penyelesaian yang telah ditetapkan antara lain dengan konsiliasi, mediasi, atau arbitrase. Penyelesaian sengketa konsumen dilakukan dalam bentuk kesepakatan yang dibuat dalam perjanjian tertulis yang ditandatangani oleh para pihak yang bersengketa, yang dikuatkan dalam bentuk keputusan BPSK (SK No. 350/MPP/Kep/12/2001 tentang Badan Penyelesaian Sengketa Konsumen Pasal 6). Putusan yang dikeluarkan BPSK dapat berupa perdamaian, gugatan ditolak, atau gugatan dikabulkan.

Dalam hubungan tersebut diatas, agar BPSK sebagai lembaga yang diberi wewenang untuk menyelesaikan sengketa konsumen dapat berperan aktif, perlu penguatan peran BPSK dimasa akan datang, yaitu pertama dengan perubahan terhadap kaedah-kaedah yang mengatur BPSK, kedua mendesain BPSK dengan memadukan model pengadilan dan model ADR (Altenative Dispute Resolution) yang "khas" Indonesia. Hal ini Nampak misalnya dari konsep BPSK yang didasarkan UUPK merupakan salah satu lembaga penyelesaian sengketa di luar pengadilan, namun dalam proses penyelesaian perkara diatur dengan " hukum acara" yang amat prosedural layaknya hukum acara perdata di pengadilan negeri.

\section{PENUTUP}

\subsection{Simpulan}

Berdasarkan penjelasan di atas, ada beberapa simpulan yang berkaitan dengan permasalahan yang dihadapi dalam praktik menyangkut eksistensi dari lembaga BPSK. Pertama, berkaitan dengan eksistensi BPSK sebagai lembaga yang masuk dalam domain pemerintah pusat ataukah pemerintah daerah. Jawaban terhadap hal ini dalam prakteknya tidak sama. Oleh karena itu, ada BPSK yang mendapat dukungan penuh dari pemerintah daerah dan ada BPSK yang kurang mendapat dukungan Pemerintah Daerah. Kedua, persoalan yang krusial adalah menyangkut tugas dan kewenangan BPSK. Ketentuan Pasal 54 ayat (3) UUPK bahwa putusan BPSK bersifat "final dan mengikat". Putusan ini menjadi kehilangan makna dan menjadi tidak berarti bagi konsumen yang mencari keadilan melalui BPSK, ketika dihadapkan dengan ketentuan Pasal 56 ayat (2) dimana terbukanya peluang mengajukan keberatan ke Pengadilan Negeri, dan ketentuan Pasal 57 UUPK mengenai permintaan eksekusi putusan BPSK kepada Pengadilan Negeri di tempat konsumen yang dirugikan. Adapun kendala-kendala yang dihadapi BPSK adalah kendala kelembagaan, keuangan, SDM, peraturan, pembinaan dan pengawasan dan kurangnya sosialisasi serta rendahnya kesadaran hukum konsumen. 


\subsection{Saran}

Perlu adanya perubahan-perubahan terhadap kaedah-kaedah yang mengatur Badan Penyelesaian Sengketa Konsumen (BPSK), sehingga BPSK dapat berperan lebih aktif serta diaktifkan kembali di daerah-daerah tingkat II .

\section{DAFTAR PUSTAKA}

Arif Rahman "Penyelesaian Sengketa Konsumen Melalui Badan Penyelesaian Sengketa Konsumen (BPSK) Kota Serang “Jurnal dalam AJUDIKASI : Jurnal Ilmu Hukum, Vol. 2 No. 1, Juni 2018

Aries Kurniawan, Peranan Badan Penyelesaian Sengketa Konsumen Dalam Penyelesaian Sengketa Konsumen, Kompas 6 Agustus 2008

Az. Nasution, “Aspek Hukum Perlindungan Konsumen”, Jurnal Teropong, Edisi Mei 2003, Masyarakat Pemantau Peradilan Indonesia

Erman Rajagukguk, "Budaya Hukum dan Penyelesaian Sengketa Perdata di Luar Pengadilan”, Jurnal Magister Hukum, PPs-UII, Yogyakarya, Volume. 2 No. 4, Oktober 2000

Kurniawan "permasalahan dan kendala penyelesaian sengketa konsumen melalui BPSK" Jurnal Dinamika Hukum, Volume 12 No. 1 tahun 2012

Muskibah "Analisis mengenai cara penyelesaian sengketa konsumen " Fakultas Hukum Universitas Jambi

Susanti Adi Nugroho, Mencari Ujung Tombak Penyelesaian Sengketa Konsumen, Hukum Online, 9 Mei 2009

, Proses Penyelesaian Sengketa Konsumen ditinjau dari Hukum acara serta kendala implementasinya, Kencana Prenada Media Group, Jakarta

\section{Peraturan Perundang-undangan}

Undang-Undang Nomor 8 Tahun 1999 Tentang Perlindungan Terhadap Konsumen.

Undang-Undang Nomor 30 Tahun 1999 Tentang Alternatif Penyelesaian Sengketa.

Keputusan Menperindag Nomor 350 Tahun 2001 Tentang Pelaksanaan Tugas dan Wewenang BPSK.

Keputusan Menperindag Nomor 301 Tahun 2001 Tentang Pengangkatan, Pemberhentian Anggota dan Sekretariat BPSK. 